\title{
Reproductive Features of Roach, Bream and Common Carp of Zaporozhian (Dnipro) Reservoir in Contemporary Environmental Conditions
}

\author{
Marenkov Oleh \\ Oles Honchar Dnipropetrovsk National University, Ukraine \\ Faculty of Biology, Ecology and Medicine, Department of General Biology and Water Bioresources \\ P.M.B. 49050, Dnipropetrovsk, Ukraine \\ Corresponding Email: gidrobions@gmail.com
}

\begin{abstract}
Keywords: roach, bream, common carp, developing gonads, young fish, artificial spawning nests,
\end{abstract} Zaporozhian Reservoir.

\begin{abstract}
Over the past 50 years, the complete histological study of carp fish gonads was first carried out at Zaporozhian Reservoir. In conditions of environmental transformation of the reservoir the regularities of oogenesis and gonadogenesis, passing sexual cycles were found and the ecology of spawning carp fish was investigated. The adaptive potential of the carp fish reproductive systems, which is expressed through the asynchrony of reproductive products development as well as the functional peculiarities of the fish spawning process, was brought to light. Both environmental assessment and faunal analysis of biodiversity and distribution of young fish of Zaporozhian Reservoir were carried out. The growth and development of the fish larvae dwelling within the industrial agglomerations of Dnipropetrovsk city are found to be under anthropogenic influence. The efficiency of the use of artificial spawning nests for the carp fish spawning was studied, and practical recommendations for their installation and operation in the waters of the reservoir were elaborated.
\end{abstract}

\section{INTRODUCTION}

The new conditions for fish existence emerged as a result of over-regulation of the Dnieper River runoff and creating cascade of reservoirs; they have caused the significant restructuring of qualitative and quantitative ichthyofaunal content [1-3]. The number of migratory and reophilic fish species gradually decreased, while the number of limnophilic fish respectively increased. The latter takes the leading position in fish catches. The runoff over-regulation regime which acts in the reservoir waters over the past 80 years has led to siltation, overgrowth of natural spawning grounds with aquatic vegetation, shoaling shallow coastal areas. As a result, throughout the reservoir water area, rather tense situation with natural reproduction of resource fish species has been formed, and the overall environmental situation of the basin has worsened on the background of intense anthropogenic impact [4].

Because of multifactor anthropogenic impact on the ecosystem of Zaporozhian Reservoir, marked changes have been observed at almost all biocenotic levels in the last 10-15 years [5]. In biocenosis structure, eurybiontic species have come to occupy the dominant position with high potential to adapt to stressful conditions of the aquatic environment. Recent studies show a steady negative trend to simplify the structure of industrial ichthyocenosis. Minor-value commercial fishery species increase their strength and keep a leading place in the fishery for several years.

Analysis of data on ichthyologic and fish-breeding research obtained in the Dnieper region reservoirs and published in the past 50 years has shown that the reproduction ecology of some valuable commercial fish species is not fully investigated [6; 7]. It remains unclear how human activities impact on life cycles of some fish, especially on the state and functioning of their reproductive systems. Recent studies of fish reproductive indexes also indicate some disorder in formation of genital products and in fertility of valuable industrial species inhabiting areas with permanent environmental stress $[5 ; 8]$. 
Research of fish gonads has not only theoretical interest, but the significant practical importance in solving a number of issues of industrial and environmental value as well.

In this context, the aim of the work was to carry out the comprehensive studies of reproductive systems of carp species in conditions of environmental transformation of Zaporozhian Reservoir using the modern histological methods, and to develop recommendations for measures, aimed at restoration of natural spawning areas and nursery grounds for young fish.

\section{MATERIALS AND METHODS}

Researches were conducted in Zaporozhian Reservoir - the multi-purpose reservoir during 2010-2014. The reservoir is located in the South-west of Ukraine, in the territory of the agroindustrial zones and been under strong anthropogenic influence [9].

Ichthyologic samplings were carried out during the growing season through research and control catches in the waters of Zaporozhian Reservoir. Fish captures were conducted at three control-observation stations located in Samara Bay $\left(48^{\circ} 53^{\prime} 40.21^{\prime \prime} \mathrm{N} ; 35^{\circ} 18^{\prime} 73.20^{\prime \prime}\right.$ E) and in the central (Monastyrskiy island - 48 $45^{\prime} 77.82^{\prime \prime} \mathrm{N} ; 35^{\circ} 08^{\prime} 32.08^{\prime \prime} \mathrm{E}$ ) and lower parts of Zaporozhian Reservoir (v. Viyskove - 48²2'30.75" N; 35²0'80.05" E) (Fig. 1).

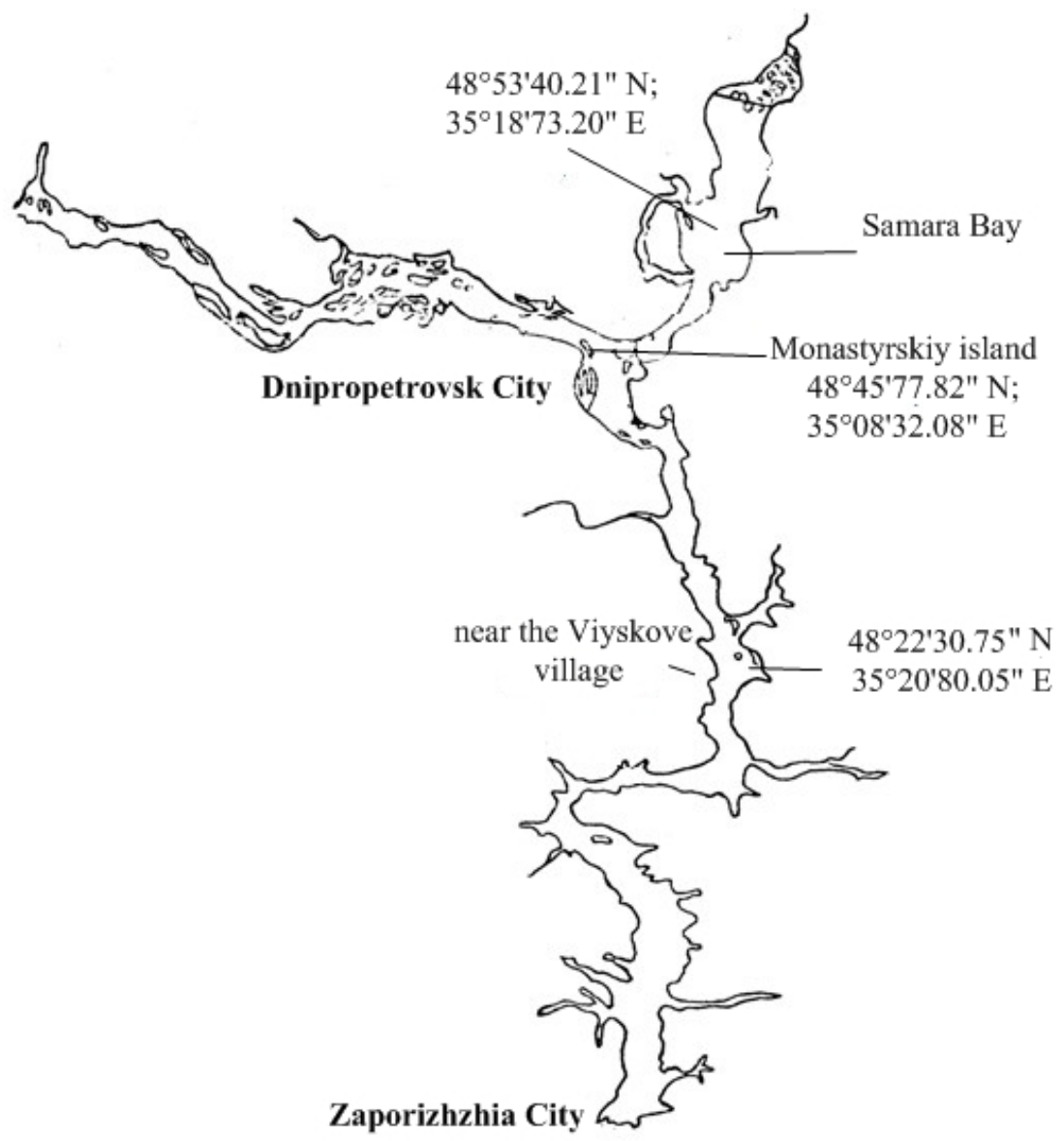

Fig. 1. The scheme of Zaporozhian Reservoir and the site of samples location

Totally, 4618 specimens of commercial fish (bream - 1480 spec., roach - 2405 spec., common carp - 733 spec.) were used for full biological analysis, 1119 samples of eggs (the bream 410 samples, the roach - 473 samples, the common carp - 236 samples) were collected and analyzed to determine the fertility, 385 histological slices of fish eggs were manufactured and analyzed, 10340 specimens of juvenile fish (the bream - 1371 spec., the roach -7981 spec., the common carp - $988 \mathrm{spec}$.) were weighed and gauged.

Research fish captures were carried out on the basis of catch permits for special use of water biological resources. The captures were committed with a standard set of stationary nets 
accordingly to the classical ichthyologic methods under the applicable law. Fishing was performed with a standard set of stake nets with mesh step of 30 to $120 \mathrm{~mm}[10 ; 11]$.

Biological analysis of fish was carried out in accordance with classical procedures in ichthyology [12]. To determine the fish age scales were taken from at least 10 individuals from each class interval of the size range. The fish age was determined by methods of V.L. Briuzgin [13] and I.I. Chugunova [14] and also by slightly modified and patented method using the VVR-1 device, whose work is based on polarizing light action [15;16]. The size-age structure of the fish populations was determined by Morozov-Mayorov method [11]. The physiological state of fish was estimated with fatness coefficients.

In order to study the fish fertility female ovaries were taken at the IV stage of their maturity. The degree of gonad maturity was determined visually. Individual absolute fecundity (IAF) was determined by weight method. Gonad-somatic index (GSI) was calculated as the ratio of gonad weights to the fish body weights shown in percentage $[10 ; 17]$.

The fish fry was caught in the third decade of July - the first decade of August in shallow water at standard control stations. Fry captures were carried out with 10-meter length webbing minnow seine of $1 \mathrm{~m}$ height, which is made of mill gas number 7 and with fingerling trawl made of capron net webbing with $4 \mathrm{~mm}$ mesh size [11]. All young fish catch was distributed by species, their numbers were counted, and measurements of their length were carried out with the accuracy up to $1 \mathrm{~mm}$ and of their individual masses - up to $0.01 \mathrm{~g}$. The number of fingerling per $100 \mathrm{~m}^{2}$ of catching area was assumed as the abundance of young fish. Fingerling species belonging was identified by A.F. Koblytska [18]. The certain fry species belonging to some kind of environmental groups was identified on the base of scientific literary information [19-23]. Using digital caliper, the full morphometric analysis by 11 indicators was carried out with young fish $(0+$ and $1+)$ caught in three areas of Zaporozhian Reservoir characterized by different degrees of anthropogenic load: Monastyrskiy island (influence of Dnipropetrovsk City), Samara Bay (impact of mineralized waters) and v. Viyskove (rather clear area of the reservoir) (Fig. 2.).

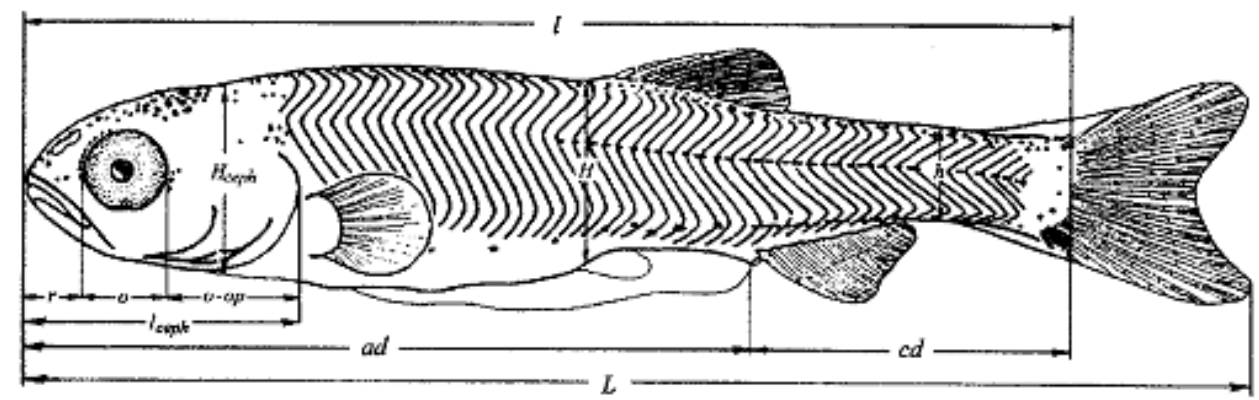

Fig. 2. Diagrammatic representation of morphology of a teleost fish fry: $L$ - total length,

$l$-standard length, $a d$ - preanal length, $c d$ - postanal length, $H$ - maximum body depth,

$h$ - minimum body depth, $l_{c e p h}$ - head length, $h_{c e p h}$ - head height, $o$-op - postorbital length, $r$ - snout length, $o$ - eye diameter [24]

In order to describe the structure of coastal communities of fish fry the following indicators were used: Sørensen index of species similarity $(S)$, index of biological diversity (entropy), which is based in its turn on Shannon index function $(H)$, system complexity index $\left(H_{m}\right)$, Foerster index of relative organization $(R)[25 ; 26]$. Dominant species of coastal ichthyocenosis were singled out with help of Mordukhay-Boltovskoy's index of coenotic value (ICV) [27]. The degree of community similarity among young fish fauna of Samara Bay and the lower part of Zaporozhian Reservoir was calculated with Sørensen coefficient [26].

With the aim to study the reproductive capacity and peculiarities of fish reproduction the female ovaries were taken at different stages of maturity. Samples were fixed in Buen's solution with followed treatment in accordance to conventional histological techniques. To produce slices, MS-2 sledge microtome was used. Slices were stained with hematoxylin-eosin and with Mallory's technique $[28 ; 29]$. Photos of preparations were made with the "Sciencelab T500 5.17 M" digital camera, which was connected to the "Biolam 70" microscope. All designations and terms used 
under describing periods and phases of growth and development of gametes, and ovarian maturity stages were those adopted in ichthyologic research.

In order to develop fish capture prognosis P.V. Turin's method [30] was used including additional methodological guidelines [11]. Statistical analysis of the experimental material was performed using Microsoft Excel and STATISTICA 6.0 software packages for personal computers.

\section{RESULTS AND DISCUSSION}

Within the frameworks of research work the comprehensive ichthyologic, physiological and histological study of spawning, fattening and coastal populations of carp species such as the roach, the bream, and the common carp - was carried out in Zaporozhian Reservoir [3; 5]. In the fish fauna of industrial populations of the major commercial species of carp fish following structural and biological changes were revealed.

The roach Rutilus rutilus (Linnaeus, 1758). The relative share of roach in catches in Zaporozhian Reservoir reduced from $48-50 \%$ to 20-25\%.The age structure of roach in industrial fishing is limited and includes 11 age classes. The number of older age groups doesn't exceed $1.5 \%$. Weighted means of roach length and weight are characterized with sufficient stability at that linear and weight parameters in females are higher than ones in males, respectively, by 10 and $33 \%$. The Fulton's condition factor amounted to $2.3 \pm 0.2$ units, indicating favorable conditions for feeding.

Individuals aged 4-6 years were the reproductive core of populations. Proportion of males and females in the spawning population amounted to $1: 1$, at that dominants were five-year specimens among females and four-year specimens among males. Small mature males aged 2 years participated in spawning as well (up to $0.4 \%$ ). Indicators of absolute fecundity (IAF) ranged from 21.3 (in 3-year group) to 120.2 thousand eggs (in 8- and 9-year groups). In the last two years weighted IAF parameter keeps up 73-77 thousand eggs. Multiplicity of roach spawning is 8 times. Coefficient of commercial return of eggs is $0.01 \%$. In the second decade of April roach females being at the IV stage of maturity have relatively high gonad-somatic index (GSI), which amounts to $29.4 \pm 6.85 \%$. In the last days before spawning the GSI increase in females to $31.5 \%$ is observed, followed by their mass spawning. The spawning period ends in late April - early May (Fig. 3).

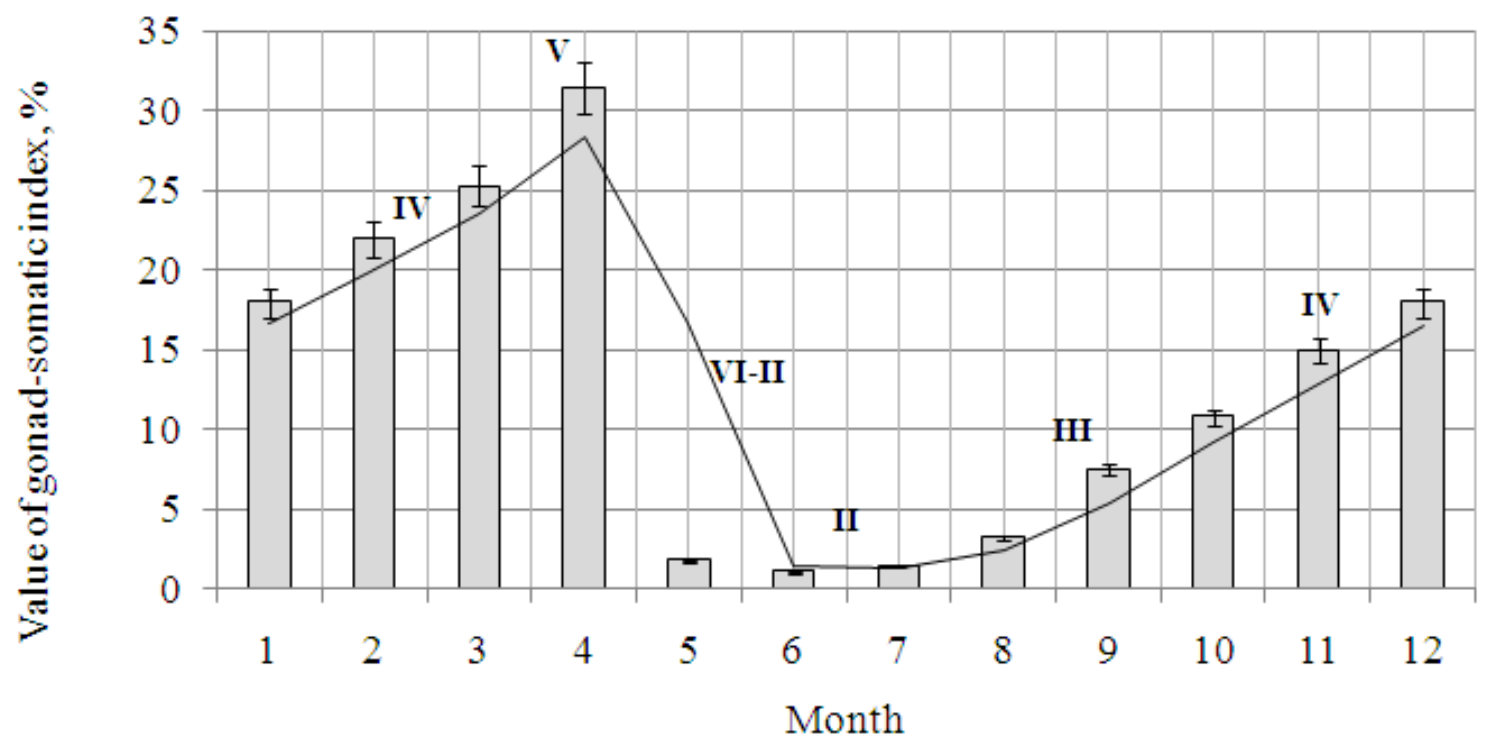

Fig. 3. Indicators of the roach GSI in different months of the year

After spawning gonads of the roach females switch to VI-II stage of maturity, containing empty follicular shells and single oocytes that undergo resorption. During this period, the GSI value reaches its minimum meanings and its average amounts to 1.1-2.3\%. Depending on water temperature, resorption processes in the roach ovaries continue about 1-1.5 months. After 
resorption, ovaries switch to the II stage of maturity, being typical for fish species with a single spawning. During this period the maturity factor is minimal, namely of 0.5-1.2. In mid-summer oocytes are in the phase of single-layer follicle - "C" phase -and have 110-195 $\mu \mathrm{m}$ diameters. The transition of the new generation of oocytes in Zaporozhian Reservoir begins during trophoplasmic growth period in late July -early August. The process of cytoplasmic vacuolation happens asynchronously and continues in some females by the end of August, and in other ones - by the end of September. Development asynchrony of female gonads in summer is likely to be caused by increased water temperatures due to abnormally high temperatures in summer period (July-August). This maturation of oocytes can be considered as an example of the adaptation of the fish reproductive system to changes in environmental conditions, especially to the temperature and water regime fluctuations in basins.

Since mid-summer to early autumn roach gonads switch to the III phase of development (passing the oocyte development phases " $\mathrm{D}_{1}$ " to " $\mathrm{D}_{3}$ "), grow and accumulate yolk, GSI increases from 3.35 to $10.8 \%$. During " $\mathrm{D}_{1}$ " phase passage, oocytes have the diameter of $220-270 \mu \mathrm{m}$. One row of vacuoles appears in the egg periphery, they are arranged as a chain, and their sizes range from 4.5 to $8.8 \mu \mathrm{m}$. Shortly the second row of vacuoles appears in oocytes and the cells go into the " $\mathrm{D}_{2}$ " phase. This phase ends with filling the peripheral part of oocyte cytoplasm with 2-3 rows of vacuoles (Fig. 4). Along with the vacuoles number increase, their enlargement is registered as well and their diameters reach $10-26 \mu \mathrm{m}$.

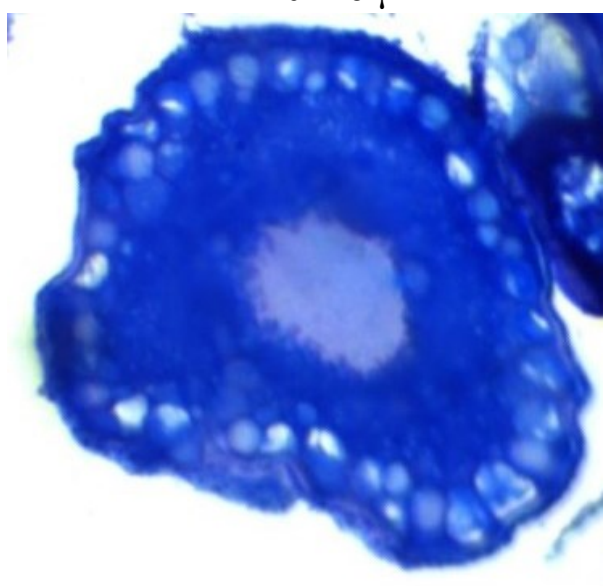

$\mathrm{D}_{1}$

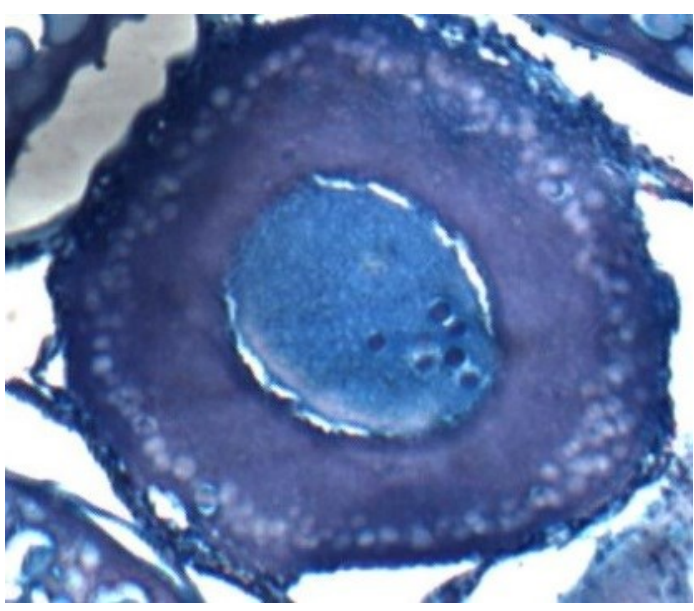

$\mathrm{D}_{2}$

Fig. 4. " $D_{1}$ " and " $D_{2}$ "phases of the third stage of the gonad development - there are rows of vacuoles visible on the oocyte periphery

With further maturation the vacuoles appear in the inner area of the cytoplasm and occupy almost the whole area up to the core. In this period, the germinal cell diameters reach 380-450 $\mu \mathrm{m}$. Then the yolk accumulates between internal and external vacuoles ("E," phase). It continues to fill the inner egg zone and the inter-vacuolar space of outer rows of vacuoles, which are pushed to the edge peripheral area. Then the yolk fills the entire oocyte (" $E_{3}$ " phase). In this period, oocyte diameters reach $720 \pm 94.5 \mu \mathrm{m}$. Since late October - early November the roach gonads come into the IV stage of maturity and in their cells the intense vitellogenesis occurs, and GSI parameter ranges from 15 to $21 \%$.

In the early winter gonads of the roach females contain, in addition to the oocytes in active phase of vitellogenesis, also cells in the phase of early accumulation of the yolk as well as oocytes of younger generations. During the completion of the yolk accumulation the process of its lumps confluence into greater formations is observed. Only before the following spring spawning the oocytes that are in phases of trophoplasmatic growth, aligned themselves in their development and switch to the "F" phase. Oocytes reach definitive dimensions, and a micropyle with a guard cell is observed in them. After this the eggs can be taken in ovulation provided the presence of favorable conditions. 
The bream Abramis brama (Linnaeus, 1758). Recently, the bream share in total catches on the Reservoir increased from $6 \%$ to $9.4 \%$. The bream age composition in fishing gears of the control order remains limited and includes 10 age classes. Number of older age groups is less than $2 \%$. Dynamics of the bream length-age parameters is characterized by stability; they remain practically at the same level over the past 20 years. The middle-aged values of the Fulton's condition factor are stable for several years and amount to $2.33 \pm 0.05$ units in females and $2.18 \pm 0.03$ units in males. Thus, the indexes of growth and physiological state show the favorable feeding conditions, sufficient supply with food resources and stable state of the bream population.

Indicators of absolute fecundity of the bream uneven-aged specimens range from 54.31 to 856.0 thousand eggs, and weighed fertility parameter is within 148-161 thousand eggs. In conditions of Zaporozhian Reservoir the spawning frequency of the bream females is 8 times. Coefficient of commercial return of eggs is $0.0025 \%$, this is consistent with the results of investigations of commercial return of the bream eggs in other reservoirs of the Dnieper.

The bream of Zaporozhian Reservoir has the longer pre-vitellogenesis period than the roach has. The bream spawning occurs in the last decade of April-the first half of May, and it starts when the water temperature reaches $13-13.5^{\circ} \mathrm{C}$. Mass spawning occurs at the water temperature of $16-18^{0} \mathrm{C}$.

By the nature of spawning the bream is characterized with single spawning but it is realized through several approaches of seed fish to the spawning grounds, so this process may take about a month. In early May, the bream females being at the IV stage of maturity had enough high GSI value $-22.1 \pm 2.2 \%$. In the last days before spawning there was the GSI increase to $24.1 \%$, after which the mass bream spawning had occurred. The spawning period ended after May, 15 (Fig. 5).

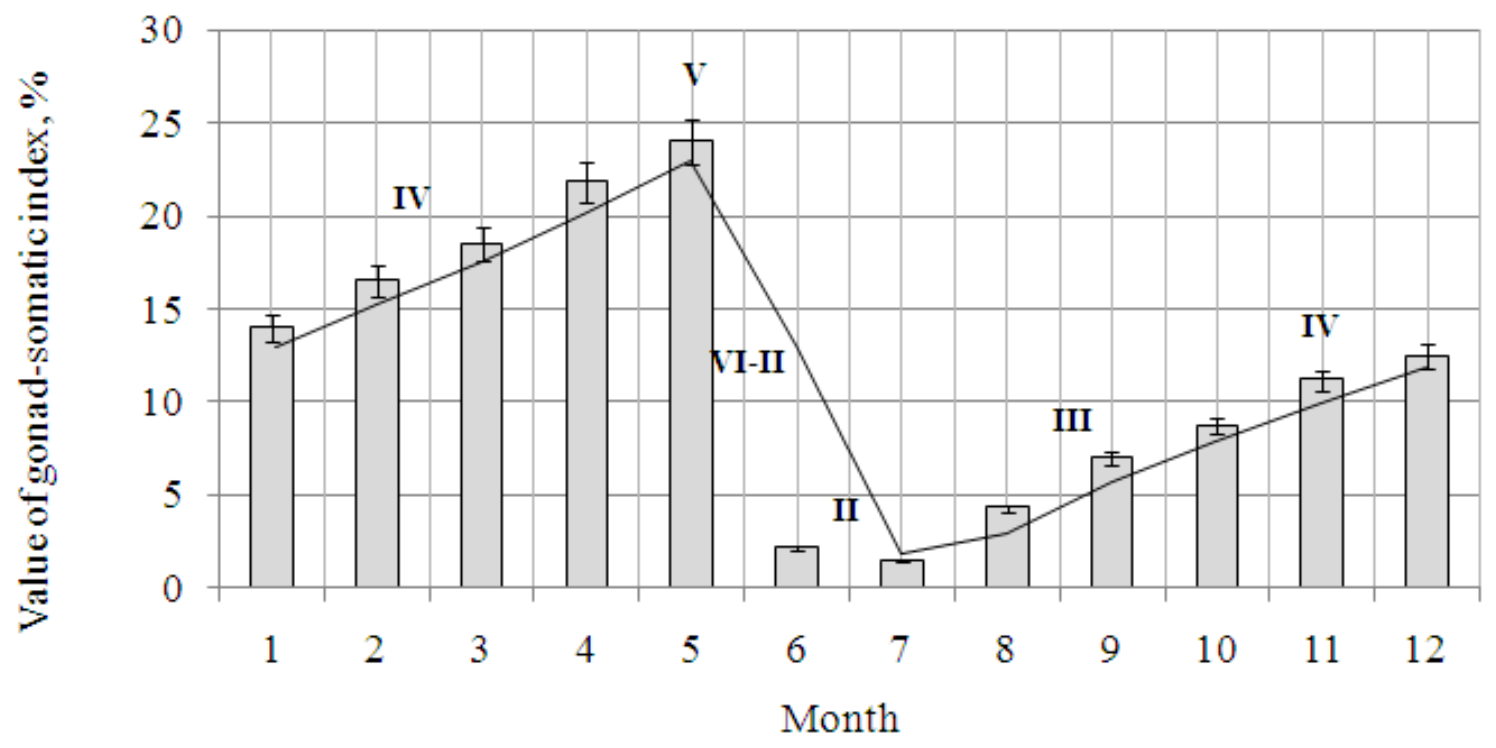

Fig. 5. Values of gonad-somatic index of the bream

After spawning gonads of the bream females switch to VI-II stage of maturity, containing empty follicular shells and single oocytes that undergo resorption. During this period, the GSI value took the least meanings and amounted to $2.14 \pm 0.1 \%$. Resorption of eggs in the bream ovaries lasts about one month. Then fish ovaries switch to the II stage of maturity, typical for fish species with a single spawning. In mid-summer the bream oocytes are in the period of protoplasmic growth and they reach the size of 120-180 $\mu \mathrm{m}$. The first vacuoles appear in the bream oocytes peripherally as a chain in the cortical layer, their number ranges from 28 to 36. During formation of the first row of vacuoles oocytes come into the " $\mathrm{D}_{1}$ " phase and their size reaches $220-270 \mu \mathrm{m}$. Then eggs go into the " $\mathrm{D}_{2}$ " phase, and vacuoles become arranged in two or more rows. Before " $\mathrm{D}_{3}$ " phase vacuoles fill in the cytoplasm totally, and cell diameter is $390-420 \mu \mathrm{m}$. Later, the cloddy yolk appears between zones with vacuoles. The yolk membrane thickens gradually ("E " continues to fill in the area inside the egg and also the inter-vacuolar space of outer rows of 
vacuoles, which are pushed to the periphery. When the " $E_{2}$ " phase has been reached, the yolk takes a half of oocyte and pushes vacuoles to the cortical area. At this time, the oocytes diameter amounts to $730-780 \mu \mathrm{m}$. While reaching the " $\mathrm{E}_{3}$ "phase the bream oocytes are completely filled with yolk and 2-3 rows of vacuoles with20-30 $\mu \mathrm{m}$ diameter remain in the cortical layer. The bream oocytes coming into the period of maturation reach the size of $800-890 \mu \mathrm{m}$. After the process of the yolk accumulation has completed, it is observed that its lumps merger into larger formations being the condensed yolk. The bream oocytes reach the definitive size. In this period cores of eggs have size of 56-126 $\mu \mathrm{m}$, and they are shifted from the center to the periphery, towards micropyle. In prespawning period eggs switch to the "F" phase, reach their maximum size (950-990 $\mu \mathrm{m})$ and then they are ready for ovulation.

Histological examinations undertaken with ovaries of the bream from Zaporozhian Reservoir show the noticeable asynchrony in oocyte development within the vitellogenesis period (Fig. 6); that is more typical for the batch spawning fish, however, in conditions of Zaporozhian Reservoir the bream lays its eggs only once and a small amount (about 6-10\%) of oocytes being in the phase of vacuolization is resorbed.

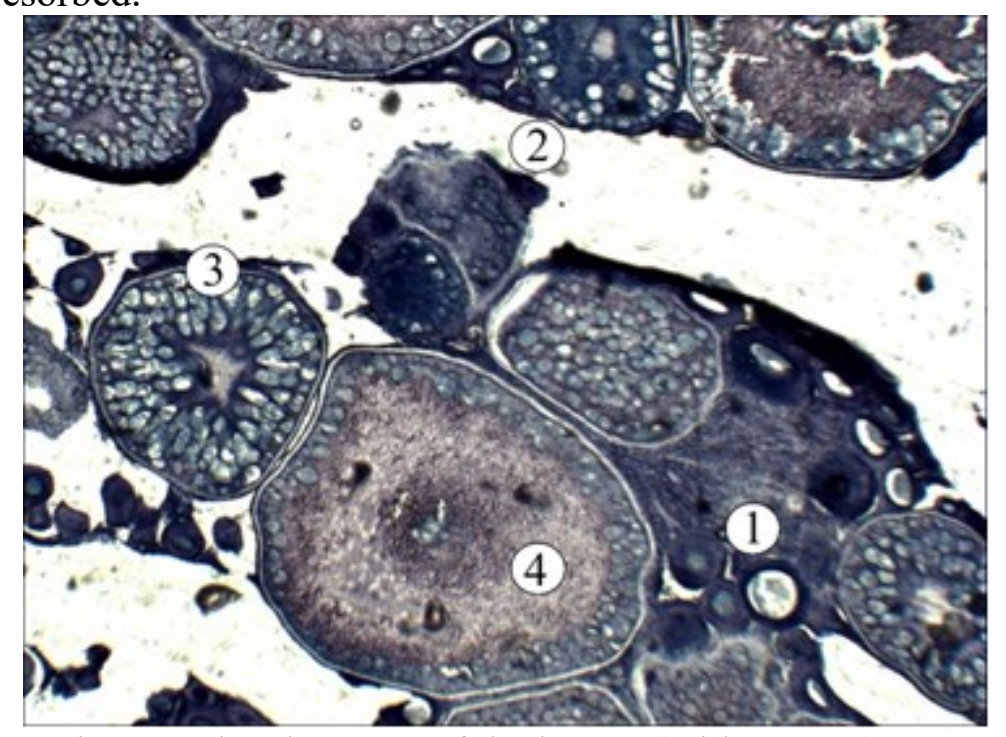

Fig. 6. Asynchrony in eggs development of the bream (mid-August): 1 - oocytes in the "C" phase; 2 - oocytes in the " $\mathrm{D}_{1}$ " phase; 3 - oocytes in the stage of vacuolization, " $\mathrm{D}_{3}$ " phase; 4 - oocytes in the late vacuolization stage, the " $\mathrm{E}_{1}$ " phase

Asynchrony in gonadal development of the bream females in the summer can be considered as an example of the adaptation of the fish reproductive system to changes in environmental conditions, especially to the temperature and water regime fluctuations in Zaporozhian Reservoir. Thus, the bream populations living in the environmental conditions of Zaporozhian Reservoir are exposed both to natural and to forced intra-population differentiation and therefore they have the specific adaptation mechanism for the reproduction.

The common carp Cyprinus carpio (Linnaeus, 1758). The relative share of the common carp in catches is not more than 1.5-2\%. The common carp age series is represented with 17 classes (3-19 years). The share of older age groups over 11 years reached $11.6 \%$, indicating the steady accumulation of older age fish in the population. Reducing the number of younger age groups shows a lack of natural replenishment of populations. Average indicators of the population were: commercial length $-57.85 \pm 1.80 \mathrm{~cm}$, weight $-4630.88 \pm 458.56 \mathrm{~g}$. In the last 5 years the Fulton's condition factor remains at a stable level and ranges from 2.00 to 3.24 units.

The individual absolute fecundity (IAF) of the common carp from different age groups ranges from 114.67 to 2195.5 thousand eggs. The average absolute fecundity of females was $627.71 \pm 32.27$ thousand eggs; it corresponds to the weighted value of fertility rate of the common carp in Zaporozhian Reservoir for the last 10 years. The ratio of males and females in the spawning population amounted to $55 \%$ and $45 \%$, respectively. Coefficient of commercial return of eggs is $0.0015 \%$. 
In late April - early May the common carp females being at the IV stage of maturity show the quite high gonad-somatic index (GSI) $-24.5 \pm 4.15 \%$.In mid-May gonads of females switch to the V stage of maturity, and GSI reaches the maximum value $-36.7 \%$ (Fig. 7 ) in this period.

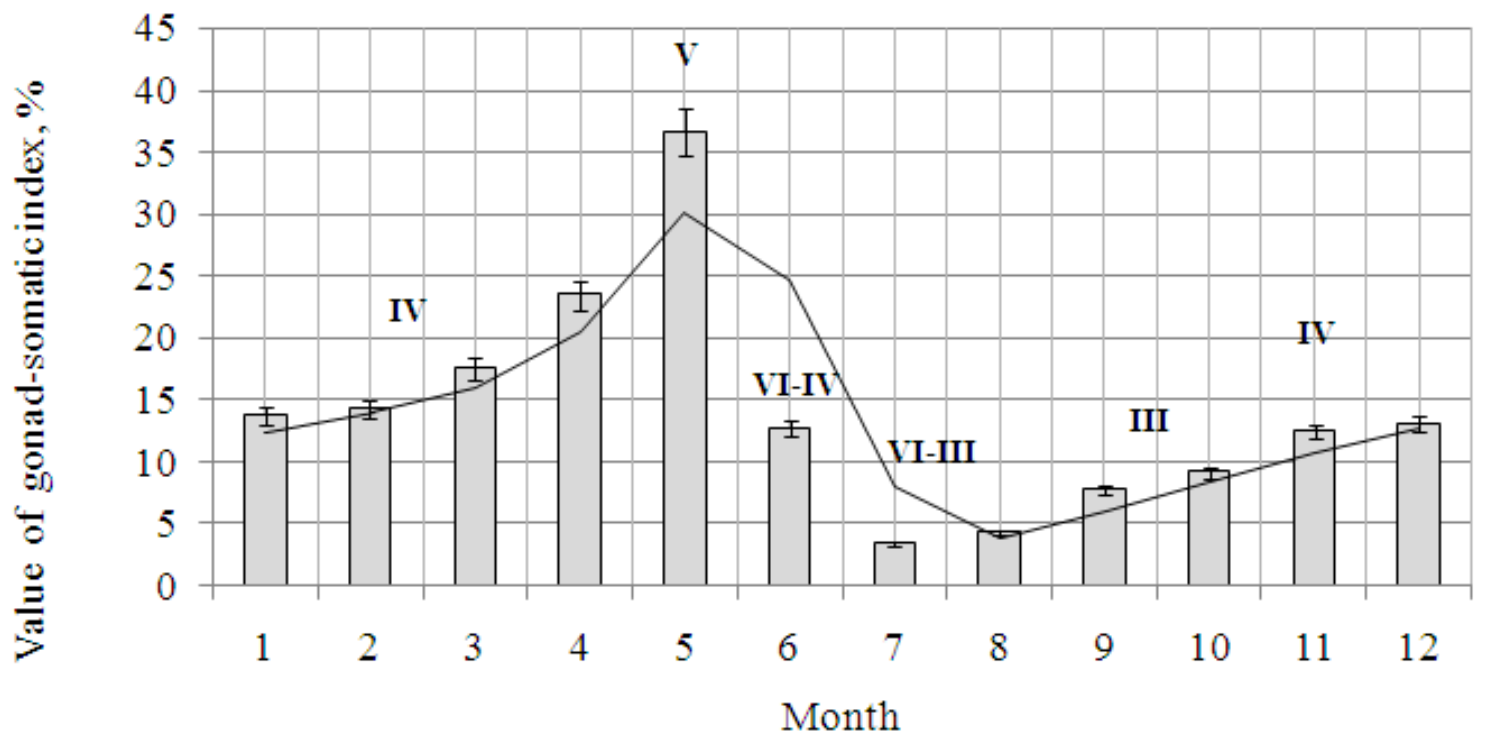

Fig. 7. Indicators of the common carp GSI in different months of the year

In conditions of Zaporozhian Reservoir the common carp is characterized with asynchronous trophoplasmatic growth of oocytes and intermittent spawning. Before spawning the common carp displays three groups of oocytes: 1) oocytes that are not filled with yolk; 2) oocytes with completed vacuolization and initiate vitellogenesis; 3) oocytes in the middle and at the beginning of vacuolization. In the phase of beginning vacuolization (" $\mathrm{D}_{1}$ " phase) one row of vacuoles with $19 \pm 5.2 \mu \mathrm{m}$ diameter is arranged on the oocyte periphery. The secondary shell with thickness of about $0.4 \mu \mathrm{m}$ is formed. The oocyte diameters in the " $\mathrm{D}_{1}$ " phase reach $300-350 \mu \mathrm{m}$. In the " $\mathrm{D}_{2}$ " phase vacuoles are evenly spaced in the outer cytoplasmic part; their diameter is $40 \pm 3.5 \mu \mathrm{m}$ and they are arranged in 2-3 rows. At the same time the whole oocyte diameter is $410-430 \mu \mathrm{m}$. In the " $\mathrm{D}_{3}$ " phase when vacuoles fill the cytoplasm totally, they are located in 5-7 rows, reduced their size and reach 16-30 $\mu \mathrm{m}$ diameters. The whole oocyte diameter is $600-630 \mu \mathrm{m}$ now. In the " $\mathrm{E}_{1}$ " phase the yolk granules first appear in areas between cytoplasmic vacuoles. At this there are 6-9vacuoles lengthwise the cell radius, and 100-120 vacuoles - circumferentially. The yolk granules are oval and they are characterized with small size. The oocyte diameter is $680-720 \mu \mathrm{m}$. In the "E,"phase the yolk occupies a half of oocyte, vacuoles are shifted to the periphery and are located in 3-4 layers. The oocyte diameter reaches $770-790 \mu \mathrm{m}$. In the "E3" $\mathrm{E}_{3}$ "phase when oocyte has completely filled with yolk, its granule diameters are in the range of 3 to $5 \mu \mathrm{m}$ in the center and $16 \mu \mathrm{m}$ at the periphery. In the late phase the oocyte diameter amounts to $1040-1060 \mu \mathrm{m}$ and the thickness of its shell is $1.8-2.2 \mu \mathrm{m}$. Definitive oocytes reach the diameter of $1.5-1.8 \mathrm{~mm}$.

The first batch of eggs contains about $80 \%$ of all eggs, the second and the third portions comprise remaining $20 \%$ of fish roe. The first portion of eggs is deposited in favorable conditions, upon higher aquatic vegetation in the spawning grounds. The second portion of fish roe is laid after a time. The third portion may not be deposited in the same season, and then it both may be resorbed and can take part in formation of the next year generation. Mass resorption of the common carp eggs is not found, but after spawning a number of oocytes remains in gonads, they are often subjected to resorption (Fig. 8). 


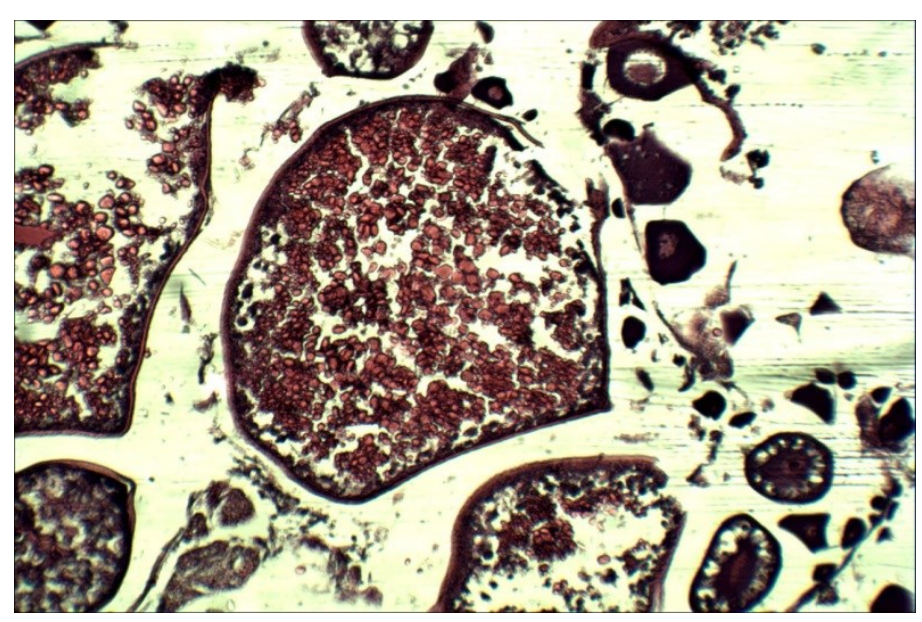

Fig. 8. The common carp ovary after shedding of the first portion of eggs: oocytes of both older and younger generations are present; there are residues of follicular membranes which undergo resorption

After spawning, the ovaries of the common carp females deposited 2 portions of eggs, are not in the II stage (as in the roach and bream), but they are in the post-spawning VI-III stage. In ovaries of the VI-III stage of maturity there are two processes occurring at the same time - on the one hand, resorption of follicular membranes and residual eggs and on the other hand, trophoplasmatic growth of new generation of oocytes. The common carp females hibernate with ovaries in the IV stage of maturity. In November the maturity factor reaches $12.5 \%$ on the average.

Species composition of fish populations of coastal habitats of Zaporozhian Reservoir and its environmental assessment. Throughout the period of study (2010-2014) the species composition of young fish of the littoral areas of Zaporozhian Reservoir totaled 35 fish species belonging to 11 families, including: Cyprinidae - 16species, Gobiidae - 7, Percidae - 3, Gasterosteidae - 2, Syngnathidae - 1, Cobitidae - 1, Esocidae - 1, Clupeidae - 1, Atherinidae - 1, Centrarchidae -1 , Siluridae -1 species. The caught species were related to 7 faunistic complexes: the tertiary plain freshwater complex -3 , the Ponto-Caspian freshwater complex -10 , the PontoCaspian sea complex -11 , the boreal plaincomplex -8 , the Chinese plain complex -1 , the American complex -1 , the boreal piedmont complex -1 species. The basis of coastal ichthyocenosis of Zaporozhian Reservoir was compounded by the fish species of the tertiary plain freshwater $(54.7 \%)$, the boreal plain $(19.5 \%)$ and Ponto-Caspian freshwater $(14.5 \%)$ faunal complexes.

In coastal areas of Zaporozhian Reservoir the growth of species diversity index is related both to the increase in the species number within the fish communities and to the decrease of the index of relative organization (Foerster index), which points to reducing the dominance degree of certain species in different years of research (Table 1). As a result, the relative contributions of different species to the total fish biodiversity were aligned.

Table 1. Environmental assessment of coastal populations of fish fry, 2010-2014.

\begin{tabular}{|l|c|c|c|c|c|}
\hline \multirow{2}{*}{ Environmental index } & \multicolumn{5}{c|}{ Years } \\
\cline { 2 - 6 } & 2010 & 2011 & 2012 & 2013 & 2014 \\
\hline Shannon index $(H)$ & 0.99 & 2.13 & 2.29 & 1.75 & 1.83 \\
\hline System complexity index $\left(H_{m}\right)$ & 4.75 & 4.91 & 4.86 & 4.95 & 4.90 \\
\hline Foerster index of relative organization $(R)$ & 0.79 & 0.53 & 0.56 & 0.65 & 0.75 \\
\hline
\end{tabular}

The dominant species of coastal ichthyocenosis of Zaporozhian Reservoir were singled out with help of Mordukhay-Boltovskoy's index of coenotic value (ICV), which takes into account the number of each species and its contribution to the total biomass. For Zaporozhian Reservoir imbalances in the structure of the coastal populations of fish fry are marked; that is expressed through availability of the dominant species with high ICV values ranging from 218.35 to 2031.51 . These fish species include the following ones: European bitterling Rhodeus amarus (Bloch, 1782), 
Roach R. rutilus, Bleak Alburnus alburnus (Linnaeus, 1758), Monkey goby Neogobius fluviatilis (Pallas, 1814). Following dominant species, the gradual aligned decrease in the index of coenotic value for the fish groups with ICV values ranging from 5 to 30, is observed; they are: prussian carp Carassius gibelio (Bloch, 1831), Black Sea sand smelt Atherina pontica (Eichwald, 1810), common verkhovka Leucaspius delineates (Heckel, 1843), round goby Neogobius melanostomus (Pallas, 1814), pseudorasbora Pseudorasbora parva (Temminck et Schlegel, 1846), bream A. brama, European perch Perca fluviatilis (Linnaeus, 1758), Common rudd Scardinius erythrophthalmus (Linnaeus, 1758) and Spined loach Cobitis taenia (Linnaeus, 1758). The ICV value for such species as European asp Aspius aspius (Linnaeus, 1758), European chubs Squalius cephalus (Linnaeus, 1758), common carp C. carpio, common zander Sander lucioperca (Linnaeus, 1758) were in the range of 0.04 to 5.22 - this indicates poor reproduction of these species and irregularities in the ichthyocenosis structure likely caused by anthropogenic factors.

In general, the overall situation concerning the fish fauna biodiversity of Zaporozhian Reservoir points at the structure disturbances of fish communities caused by man-made factors. Among representatives of commercial ichthyofauna, the roach young fish is the most common in shallow waters of the Dnieper cascade reservoirs [31]. It occurred to catch at all points of observation. Over the research period the roach fingerling number observed in 2012 was 24.58 ind./ $100 \mathrm{~m}^{2}$ with the highest one in $2010-99.0$ ind. $/ 100 \mathrm{~m}^{2}$, while the young roach biomass reached $37.36 \mathrm{~g} / 100 \mathrm{~m}^{2}$ and $198.5 \mathrm{~g} / 100 \mathrm{~m}^{2}$, respectively. Thus, natural reproduction of the roach in Zaporozhian Reservoir can be characterized as satisfactory.

The bream fingerlings were quite common and occurred in all parts of basins. The greater number of the bream inhabited the lower part of Zaporozhian Reservoir. The bream population replenishment with new generations occurred every year, but not to the same extent, the fish yield in coastal areas of Zaporozhian Reservoir declined from $6.50 \mathrm{ind} . / 100 \mathrm{~m}^{2}$ (2010) to $2.38 \mathrm{ind} . / 100 \mathrm{~m}^{2}$ (2012) and 0.75 ind. $/ 100 \mathrm{~m}^{2}$ (2013). Biomass, which is created with the bream fingerlings in the intertidal zone of the reservoir, also varies in a wide range from $2.39 \mathrm{~g} / 100 \mathrm{~m}^{2}$ to $46.80 \mathrm{~g} / 10 \mathrm{~m}^{2}$. Thus, the bream reproduction in Zaporozhian Reservoir is at an unsatisfactory level.

Young fish of the common carp occurred only in certain parts of the reservoir and preferably at the beginning of the growing season. It was noted in sufficiently large quantities in the lower part of Zaporozhian Reservoir, within Viyskove village and in Vorona, Krupskaya and Zvonetskaya cloughs - in this part the common carp fingerling abundance reached 2.45 ind.$/ 100 \mathrm{~m}^{2}$ on the average. In Samara Bay the common carp fry occurred in biotopes of reed beds, thickets of flowering rush and pond grass that grew both on the muddy bottom and on the sandy one. In the total reservoir, the common carp fingerling abundance ranged from $0.07 \mathrm{ind} . / 100 \mathrm{~m}^{2}(2010 \mathrm{index})$ to 0.86 ind. $/ 100 \mathrm{~m}^{2}$ (2011 index). For the last two years the common carp fingerling abundance is within the range of 0.4 to 0.5 ind.$/ 100 \mathrm{~m}^{2}$. Over the research period the biomass that was created in the intertidal zone of Zaporozhian Reservoir by the common carp fingerling, ranged from 3.36 to $14.41 \mathrm{~g} / 100 \mathrm{~m}^{2}$. Thus, the common carp reproduction in Zaporozhian Reservoir is at the unsatisfactory level.

Influence of anthropogenic factors on fish communities of different areas of Zaporozhian Reservoir. The results of cluster analysis of morphometric parameters of one-yearold and two-year-old fish showed that the young fish caught in the lower part of Zaporozhian Reservoir (near the Viyskove village) was different from the young fish caught near the Monastyrskiy island and in Samara Bay, where the fish morphometric parameters were smaller (Fig. 9).This phenomenon is likely caused by anthropogenic impact on aquatic ecosystems of the studied areas.

So technogenic loading due to industrial and communal enterprises of Dnipropetrovsk City as well as environmental conditions of Samara Bay affects not only the diversity of fish species, but also the development of young fish, reducing the performance of its morphological characteristics. Therefore, the morphological indices of young fish might be used to assess the degree of anthropogenic impact on the aquatic ecosystem. 
Integral assessment of quantitative indicators of commercial species. Taking into account the ratio of natural ( 0.21$)$ and overall mortality (44.3\%), the roach stock in Zaporozhian Reservoir culated for 2015 amounted to 748 tons by volume. The development of limits in earlier years was at $65-80 \%$ level. With optimal catch near $25 \%$, the recommended limit setting for the roach catch is to be to the extent of 187 tons. Taking into account the ratio of natural $(23.9 \%)$ and overall mortality (47.1\%) of the roach in 2014, the roach stock in Zaporozhian Reservoir predicted for 2016 is estimated in the amount of 998 tons. With the optimal catch it is recommended to increase the roach catch limit in 2016 and to set it at the level of 200 tons.
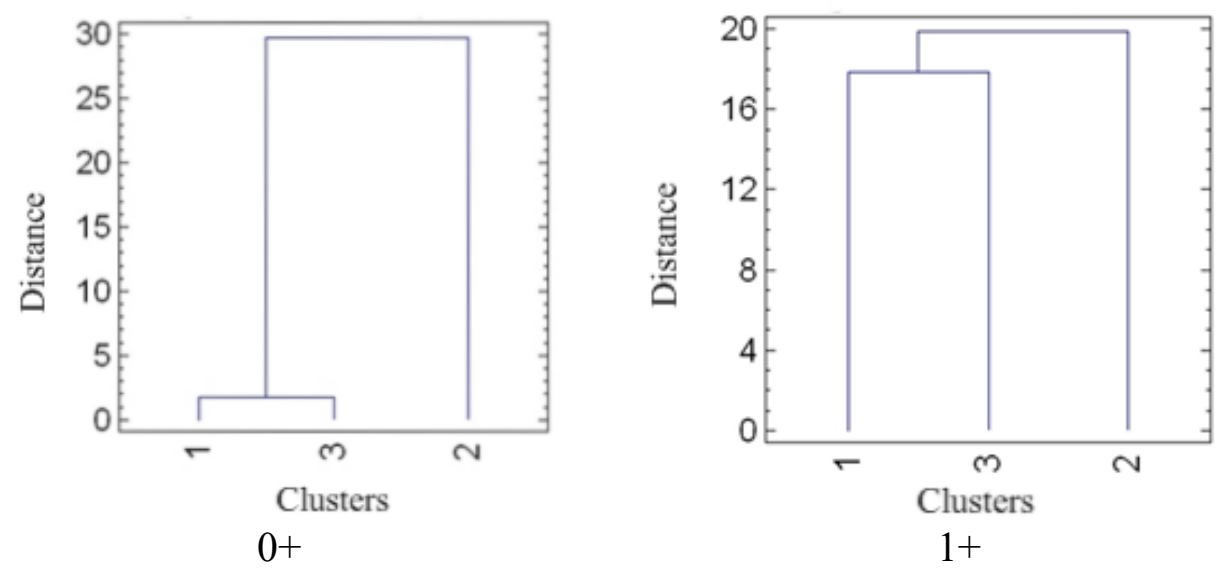

Fig. 9. The results of cluster analysis of morphological parameters of one-year-old $(0+)$ and twoyear-old (1+) fish from different parts of the reservoir: Monastyrskiy island (1), v. Viyskove (2), Samara Bay (3)

The development of the bream catch limits keeps the level of $90 \%$ in recent years. Taking into account the coefficient of natural mortality $(0.18)$, and the catch rate $(0.28)$ the bream stock calculated for now amounts to 389 tons. But the low rates of replenishment with fish youth, middleaged female bias in the direction of the younger age groups demonstrate feasibility to set the bream catch limit for 2015 no higher than 80 tons. To calculate the bream stock for 2016 it is found that the natural mortality rate reached 0.22 , and the rate of capture -0.27 . Factored in realization of rational fisheries in 2015, the bream stock in Zaporozhian Reservoir estimated for 2016 is about 340 tons. It is advisable to set the bream catch limit in 2016 at the level not exceeding $25 \%$ of the total stock - that is 85 tons.

The common carp stock for 2015 year is estimated as 438 tons, and the forecast for the common carp allowable withdrawal in 2015 amounts to 25 tons. According to research results obtained in 2014 it has been found that the natural mortality rate of reached 0.13 , and the total mortality rate -0.36 . The modern common carp stock in Zaporozhian Reservoir can be estimated as 340 tons. Factored in the relatively low rates of quotas development (at the level of 30-60\%), the forecast for the common carp allows its withdrawal in 2016 in amount of 21 tons.

Efficiency of artificial spawning grounds using. Research of efficiency of artificial spawning grounds using in the waters of Zaporozhian Reservoir was carried out. The artificial spawning nest represented the net webbing from nylon material with $12-16 \mathrm{~mm}$ mesh fixed on a metal hoop (Fig. 10).

4000 units of artificial spawning grounds were installed in the lower part of Zaporozhian Reservoir. They effectively protected the egg laying from acute changes of the water level in the reservoir. It was estimated that phytophilous fish deposited their eggs in 3000 spawning grounds. On the average, spawning fish deposited about $72 \mathrm{~g}$ of fish roe per 1 spawning grounds. Each gram of the fish roe contains about 320 eggs. The percentage of larvae release from eggs reached $82 \%$. Thus, as a result of these experiments, use of the spawning nests gives the possibility to get about $56,680,000$ fish larvae. So the artificial spawning grounds positively influence on the reproduction of the carp fish in Zaporozhian Reservoir. 
To improve the reproduction conditions for fish resources it is necessary to gradually increase the annual number of spawning grounds up to their optimal number - 120 thousand units including the annual supplement: in 2016 - 40 thousand units; in 2017 - 20 thousand units; in $2018-30$ thousand units; in 2019 - 30 thousand units. Use of artificial spawning nests will allow optimizing the natural reproduction and reconditioning 2 ha of effective spawning grounds by 2019.

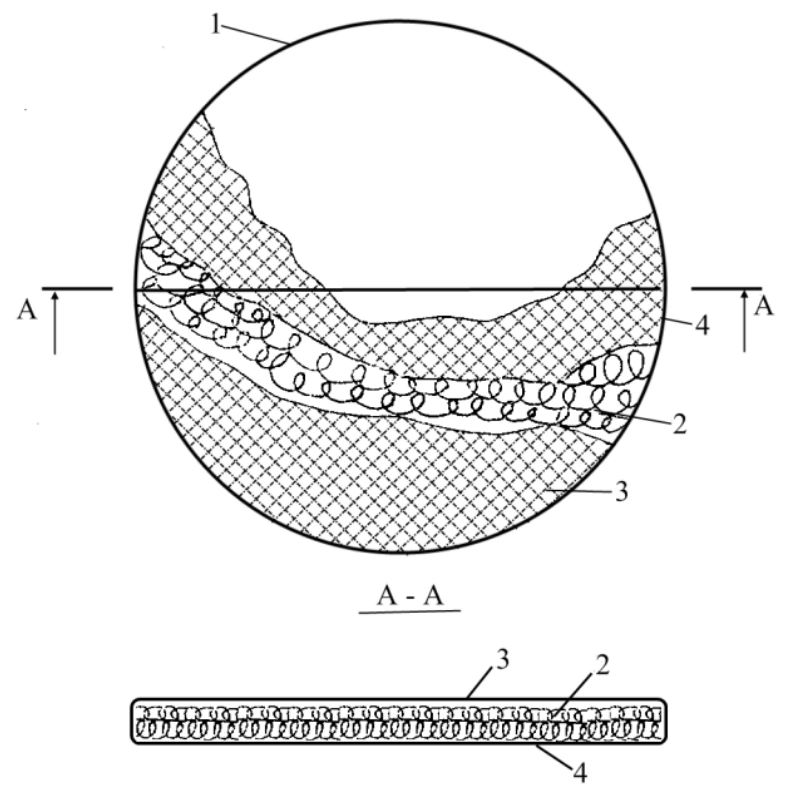

Fig. 10. Scheme of artificial spawning ground, a top view and a sectional view along A-A: 1 - a metal frame 2- spawning substrate 3-4 - upper and lower layers of the network fabric

\section{CONCLUSIONS}

The state of spawning populations of the carp fish was investigated in conditions of ecological transformation of Zaporozhian Reservoir. Regularities of oogenesis and gonadogenesis of roach, bream and common carp were found. The adaptive potential of reproductive systems of the carp fish, which is expressed through the asynchrony of sexual products development and the functional peculiarities of the fish spawning process, was displayed. According to results of the research, the following conclusions might be formulated:

1. The relative share of the roach in catches within the Zaporozhian Reservoir reduced from $48-50 \%$ to $20-25 \%$. The roach age structure in the fishery is limited and includes 11 age classes. Number of older age groups does not exceed $1.5 \%$. The roach average length as well as weight from year to year is characterized by sufficient stability; upon that the linear and weight parameters of females are higher than those of males by 10 and $33 \%$, respectively. Indexes of absolute fecundity range from 21.3 (in 3-years-old fish) to 120.2 thousand eggs (in 8- and 9-years-old fish). Over the last two years the average individual absolute fecundity keeps the level of 73-77 thousand eggs.

2. The process of cytoplasm vacuolization in the roach oocytes occurs asynchronously and continues in some females by the end of August, and in others - by the end of September. Asynchronous development of the female gonads is caused by abnormally high temperatures in summer at the time of the research. After the intensive vitellogenesis completion, oocytes are aligned in their development and the single generation of oocytesis under preparation, those will take part in spawning.

3. Recently, the bream share in total catches within the reservoir increased from $6 \%$ to $9.4 \%$. At what the bream age structure remains limited and includes 10 age classes. Number of older age groups is less than $2 \%$. The dynamics of the bream linear-age indicators is characterized by stability over the past 20 years. At the time of the research the dominance of the male number over the female number is marked in the structure of the bream spawning populations that is the 
result of adverse changes in environmental conditions of Zaporozhian Reservoir. In addition, there is a low level of female migration to the spawning grounds, particularly because of poaching capture during the spawning period. The absolute fecundity of the bream individuals of different ages fluctuates from 54.31 to 856.0 thousand eggs, and the average weighted fertility is within 148161 thousand eggs over the past two years.

4. Histological study of the bream ovaries carried out for Zaporozhian Reservoir, showed the significant asynchrony of oocytes development within the vitellogenesis period; that is more typical for the batch spawning fish, but in the media of Zaporozhian Reservoir the bream lays only one portion of eggs, and a small amount (about 6-10\%) of its vacuolization phase oocytes is resorbed. Thus, in the modern environmental conditions of Zaporozhian Reservoir the bream populations are exposed to the natural and forced intra-population differentiation, and therefore they have the specific adaptation mechanism for their reproduction.

5. The relative share of the common carp in catches doesn't exceed 1.5-2\%. The age range of the common carp is represented with 17 classes (3-19-years-old fish). The share of older age groups over 11 years reaches $11.6 \%$, indicating on the steady accumulation of older age groups in the population. Reducing the number of younger age groups testifies to insufficient replenishment of the population. The individual absolute fecundity of the wild carp of different age groups ranges from 114.67 to 2195.5 thousand eggs.

6. In conditions of Zaporozhian Reservoir the common carp is characterized with asynchronous trophoplasmatic growth of oocytes and with batch spawning. Before spawning oocytes of the common carp differentiate into three groups, which are prepared to be deposited as three portions of eggs. The first portion of the fish roe contains about $80 \%$ of the eggs, the second and the third portions comprise remaining $20 \%$ of the fish roe. After spawning, in the common carp females, which deposited 2 portions of eggs, the ovaries are not at the II stage (as in roach and bream), but they are at the post-spawning VI-III stages.

7. The research results showed the unsatisfactory state of commercial fish fauna reproduction concerning the fish fry number. Environmental assessment of coastal fish populations displayed imbalances in ichthyocenosis state. Only the roach populations are characterized with satisfactory replenishment both in number and in biomass; at the same time the natural replenishment of the bream and common carp remains poor. Results of cluster analysis also indicate the adverse impact of anthropogenic factors on the growth and development of young commercial fish.

8. In 2015 the roach limiting catch should amount to 187 tons, the bream limiting catch -80 tons, and forecast for the common carp catch -25 tons. In2016 the roach limiting catch should amount to 200 tons, the bream limiting catch -85 tons, and forecast for the common carp catch 21 tons.

9. To improve the reproduction conditions for fish resources it is necessary to gradually increase the annual number of spawning grounds up to their optimal number - 120 thousand units including the annual supplement: in 2016 - 40 thousand units; in 2017 - 20 thousand units; in 2018 - 30 thousand units; in 2019 - 30 thousand units. Use of artificial spawning nests will allow optimizing the natural reproduction and reconditioning 2 ha of effective spawning grounds by 2019.

The research results became the basis of regulatory documents for the order of industrial fishing in Zaporozhian Reservoir on 2011-2016, including "Limits and prognoses of the acceptable special use of water biological resources of national importance in the Dnieper reservoirs in 2015" approved by the decree of the Ministry of Agrarian Policy of Ukraine from 27.10.2014№ 428, and "Mode of fisheries in Dnieper reservoirs in 2015" approved by the decree of the Ministry of Agrarian Policy of Ukraine from 30.12.2014, №509. 


\section{REFERENCES}

[1] V. D. Romanenko, S. A. Afanasiev, V. B. Petukhov et al., Effects of fishery on biological diversity within the Dnieper river basin. Definition of gaps and problems, Kiev, Ukraine, 2003.

[2] I. Yu. Busevich, Status and prospects of using the commercial ichthyofauna of large plain reservoirs of Ukraine: Author's abstract of thesis for a doctor's degree in biology, Kiev, Ukraine, 2012.

[3] O. V. Fedonenko, Influence of anthropogenic factors on the condition of commercial fish fauna of Zaporozhian Reservoir: Author's abstract of thesis for a doctor's degree in ecology, Odessa, Ukraine, 2010.

[4] O. V. Fedonenko, N. B. Esipova, T. S. Sharamok et al., Modern problems in hydroecology: Zaporozhian Reservoir, Dnipropetrovsk, Ukraine, 2012.

[5] M. M. Shykhshabekov, E. V. Fedonenko, O. N. Marenkov, N. M. Abdullaeva, N. I. Rabazanov, Adaptive potential and functional features of reproductive systems of fish in environmentally transformed reservoirs, Dnepropetrovsk, Ukraine, 2014.

[6] L. B. Reinhard, T. N. Zabud'ko-Reinhard, T. K. Trudova, Comparative characteristics of the year gonad development cycle of the basic commercial fish of the Lenin lake. Procs. Of conclud. conf. of DGU, Dnepropetrovsk, USSR, 1961, 51-52.

[7] V. I. Vladimirov, L. G. Sukhoyvan, C. S. Bugay, Reproduction of fish in conditions of overregulated runoff of rivers, Kiev, USSR, 1963.

[8] L. V. Chepurnova, Functional changes of gametogenesis and sexual cycle in semi-anadromous fish of Dniester at abusing conditions of migration and spawning: Author's abstract of thesis for cand. degree in biol. sci., Leningrad, USSR, 1964.

[9] O. V. Fedonenko, T. S. Sharamok, Environmental assessment of key areas of Zaporozhian Reservoir fisheris (Ukraine), Ecological Bulletin of the North Caucasus. 11 (2015) 45-50.

[10] O. M. Arsan, O. A. Davydov, T. A. Dyachenko et al., Methods of hydroecological investigation of surface waters, Kiev, Ukraine, 2006.

[11] S. P. Ozinkovska, V. M. Yerko, G. D. Kokhanova et al., Technique of collecting and processing of ichthyological and hydrobiological materials with the aim to determine the limits of commercial fishing regarding large reservoirs and limans of Ukraine, Kiev, Ukraine, 1998.

[12] I. F. Pravdin, Guide for studying fish (predominantly fresh-water). Moscow, USSR, 1966.

[13] V. L. Bryuzgyn, Methods of fish growth study by $\quad$ scale and otoliths, Kiev, USSR, 1969.

[14] I. I. Chugunova, Guide for studying age and growth of fish (Methodical manual on ichthyology), Moscow, USSR, 1959.

[15] I. I. Grytsynyak et al., Device VVR-1 for determining the fish age, Patent of Ukraine № u201404128. 10.09.2014.

[16] I. I. Grytsynyak et al., Method of determining the fish age, Patent of Ukraine № u201404127. 10.27.2014.

[17] Ashwini G. Ghanbahadur, Girish R. Ghanbahadur, Study of gonadosomatic index of fresh water fish Cyprinus carpio, DAMA International. 1 (2012) 32-33.

[18] A.F. Koblitskaya, The determinant of freshwater fish juvenile, 2nd ed., Moscow, USSR, 1981.

[19] G. V. Nikolskiy, Ecology of fish, Moscow, USSR, 1963.

[20] G. V. Nikolskiy, Particular ichthyology, Moscow, USSR, 1971.

[21] G. V. Nikolskiy, About biological specificity of faunistic complexes and significance of its analysis for zoogeography, Zool. J. 3 (1947) 221-232.

[22] G. V. Nikolskiy, Species structure and regularities offish variability, Moscow, USSR, 1980.

[23] Yu. A. Pesenko Principles and methods of quantified analysis in faunistic investigations, Moscow, USSR, 1982. 
[24] A. P. Petlina, V. I. Romanov, Study of fresh-water fish juveniles of Siberia, Tomsk, 2004.

[25] E.C. Pielou Mathematical Ecology, New York, 1977.

[26] E. Magarran, Ecological diversity and its evaluation, Moscow, 1992.

[27] F. D. Mordukhay-Boltovskoy, Methodology for studying biogeocenosis of inland water bodies, Moscow, USSR, 1975.

[28] E. V. Mikodina, M. A. Sedova, D. A. Chmilevskiy, A. E. Mikulin, S. V. Pianova, O.G. Poluektova, Histology for ichthyologists: Experience and recommendations, Moscow, 2009.

[29] S. Mumford, J. Heidel, C. Smith, J. Morrison, B. Macconnell, V. Blazer, Fish Histology and Histopathology, 4th Edition, US Fish \& Wildlife Service, West Virginia, 2007.

[30] P. V. Tyurin, Theoretical grounds of rational regulation of fishery, Leningrad, USSR, 1973.

[31] G. O. Kotovska, D. S. Khristenko, Conditions and efficiency of reproduction of the major commercial fish species of Kremenchug reservoir, Kiev, Ukraine, 2010. 